\title{
Conceptual design of a seawater desalination system using a heat pump.
}

Diseño conceptual de un sistema de desalinización de agua de mar utilizando una bomba de calor.

DOI: https://doi.org/10.25043/19098642.195

Leslie L. Díaz Heyser ${ }^{1}$

\begin{abstract}
The present investigation is based on the development of a conceptual design of a desalination system incorporating the technology of the heat pump, for which the conceptual foundations related to water and its characteristics were addressed; a description of the different desalination systems and technical characteristics of a heat pump. The information collected allowed to start the development of the methodological framework, in which the lineal design model was applied to define the parameters and requirements that were considered to determine the conceptual design of the desalination system using a heat pump, through which, the main result was that the heat pump technology is applicable to a seawater desalination system, considering the seawater conditions on the coast of Chile and the standardized flows that the Navy could require.
\end{abstract}

Key words: COP: Coefficient Of Performance; the efficiency of a refrigerator or heat pump is given by a parameter, $P S U$ : Practical Salinity Unit. $1[\mathrm{PSU}]=1[\mathrm{~g} / \mathrm{kg}]=$ one gram of salt per kilogram of water, $Q_{E V}$ : Heat in the evaporator $[W], Q_{T}$ Heat in the condenser $[W], \dot{W}$ : Work done by the system $[W]$.

\section{Resumen}

La presente investigación se sustenta en el desarrollo de un diseño conceptual de un sistema de desalinización incorporando la tecnología de la bomba de calor, para lo cual se abordaron los fundamentos conceptuales relacionados con el agua y sus características; una descripción de los diferentes sistemas de desalinización existentes y características técnicas de una bomba de calor. La información recopilada permitió iniciar el desarrollo del marco metodológico, en el cual se aplicó el modelo de diseño lineal para definir los parámetros y los requisitos que se consideraron para determinar el diseńo conceptual del sistema de desalinización utilizando una bomba de calor, a través del cual, se obtuvo como principal resultado que la tecnología de la bomba de calor es aplicable a un sistema de desalinización de agua de mar, considerando las condiciones del agua de mar en la costa de Chile y los caudales estandarizados que la Armada podría requerir.

Palabras claves: $C O P$ : Coeficiente de rendimiento; $P S U$ : Unidad práctica de salinidad; $\dot{Q}_{E V}$ : Calor en el evaporador $[W] ; \dot{Q}_{T}$ : Calor en el condensador $[W] ; \dot{W}$ : trabajo realizado por el sistema $[W]$.

Date Received: February 6 $6^{\text {th }} 2019$ - Fecha de recepción: Febrero 6 de 2019

Date Accepted: March 10 2019 - Fecha de aceptación: Marzo 10 de 2019

${ }^{1}$ Armada de Chile. Talcahuano, Región del Biobío, Chile. Email: ldiazh@dgtm.cl 


\section{Introduction}

Water is a fundamental element for the human being: without water, there is not life. Currently, the world population has been increasing and in various parts of the world there has been water shortage, either due to long periods of drought, changes in climate, because the existing water is contaminated, among others. Of the total water in the world, around $97.5 \%$ is present in oceans and seas, and of the remaining $2.5 \%, 0.007 \%$ is available for human consumption. Due to the shortage of fresh water and the large amount of water available in oceans and seas, it is that, throughout history, technologies have been developed to obtain water for human consumption from salt water, emerging the concept of "desalination", for which, there are two main methods: one through the change of phase of the water, either by evaporation or freezing; and the other through the use of membranes, such as reverse osmosis or electrodialysis, on which various techniques have been developed for their execution. On the other hand, there is a technology widely used in air conditioning: the heat pump. A heat pump is a system that uses a refrigeration cycle to transfer heat energy from one place to another, generating a low temperature source and a high temperature source. From the above, the following problem arises: Is the technology of the heat pump applicable to water desalination processes?

The general objective of the present titration work is: "Conceptually design a desalination system for seawater using a heat pump".

The following specific objectives are:

1. Define the basic concepts related to the seawater desalination process.

2. Describe current systems of water production from seawater.

3. Describe basic concepts of a heat pump.

4. Describe generically a desalination process with a heat pump.

5. Determine parameters that will be considered in a water desalination process using a heat pump.

6. To theoretically calculate the technical capacities that the heat pump must have for different volumes that will be generated.

7. Identify the dimensions of the heat pump equipment.

8. Conceptually define the design of the heat pump according to the established parameters.

The methodology used for the present work of degree is applied research, developing in a first stage, about the conceptual foundations related to water and its characteristics; desalination; and concept of a heat pump. In the second stage, the methodological framework based on the lineal design model, which consists of five stages: identification of the idea, conceptual design, preliminary design, detailed design and final design, taking into account that, the present study is oriented finally to propose a "conceptual design". The conceptual design is defined as: "the set of tasks aimed at obtaining a solution to a problem raised from the specifications, requirements and needs" (Alteaga, 2016), which involves the properties, attributes, functions, schemes and sketches of a product, in this particular case, of the conceptual design of a seawater desalination system using a heat pump.

\section{The water and its characteristics}

The first concept that must be defined is water, since it is not enough to say that it is a chemical element composed of two hydrogen atoms and one of oxygen, but that one must differentiate sea water, fresh water and drinking water. Seawater is one that has about 30 [psu] of salinity or more, that is 30 grams of salts per liter of water and is not suitable for human consumption, the average of the world salinity is 35 [psu], the Baltic Sea being the lowest salinity with a salinity of 3 to 8 [psu] and the largest one the Dead Sea with 265 [psu]. Fresh water is one that has 0.3 [psu] or less, which does not make it suitable for human consumption, since by definition it does not discriminate if it is cloudy water, with microorganisms, radioactive elements, etc. The water that is suitable for human consumption is potable water, a subdivision of fresh water that indicates that it meets the parameters of turbidity, chemical, microbiological and radioactive elements determined by each state, since the conditions must 
be contextualized by geographical areas. In Chile, the superintendence of sanitary services established the parameters of drinking water through the standard of water purification.

Water is a vital resource for living beings, either directly, through the consumption and daily use of the resource, or indirectly, through its use in the mining industry and agriculture, the Fig.1 shows the distribution of water use in Chile.

Fig. 1. Water use in Chile (Cáceres, 2016).

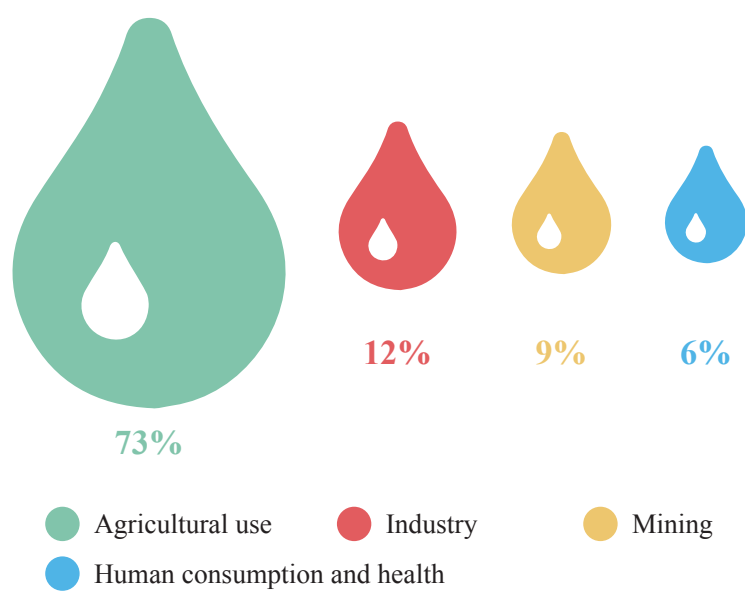

According to a study carried out by Aguas Andinas, a Chilean family of 5 people consumes an average of 30,000 [L] of water in a month, which refers to direct uses of water (see detail in Table 1), which is equivalent to a monthly consumption of approximately $6,000[\mathrm{~L}$ ] per person, that is $200[\mathrm{~L}]$ per day.

Table 1. Water consumption of a family of 5 people in Chile (Aguas Andinas, 2017).

\begin{tabular}{lr}
\hline \multicolumn{1}{c}{ USE } & $\begin{array}{r}\text { WINTER [L] } \\
\text { Shower }\end{array}$ \\
\hline Toilet flushing & 300 \\
\hline $\begin{array}{l}\text { Preparation of meals and } \\
\text { washing dishes }\end{array}$ & 80 \\
\hline General washing & 200 \\
\hline Water plants & 5 \\
\hline Total per day & 835 \\
\hline Total per person in one day & 167 \\
\hline Total in a month & 25.050 \\
\hline
\end{tabular}

The World Health Organization (WHO) warns that, due to various factors such as climate change, demographic changes and the same advances in urbanization, by 2025 half of the world's population will live in areas with water shortages, what is really important is to look for alternatives to generate water for a sustainable future.

\section{Desalination}

The desalination of seawater is the action of separating water from its salts and for this there are different methods, the main ones being through the change of phase of the water, either by evaporation or freezing; or through membranes, such as electrodialysis or reverse osmosis. On board the units of the Chilean Navy, reverse osmosis and evaporation are mainly used, for the present study the concept of desalination by evaporation will be explained, since it will be used later for the development of the conceptual design.

A system of desalination by evaporation is composed of two main elements, an evaporator and a condenser (Fig. 2). In the evaporator the water changes from liquid phase to vapor, separating from the salts, for this it needs an external source of heat. Subsequently, the steam passes to the condenser where energy is extracted to achieve the change of phase from vapor to desalinated liquid. Currently, the most commonly used heat sources are boilers and heat reuse of engine exhaust gases.

Fig. 2. Evaporator (La desalinización, 2017).

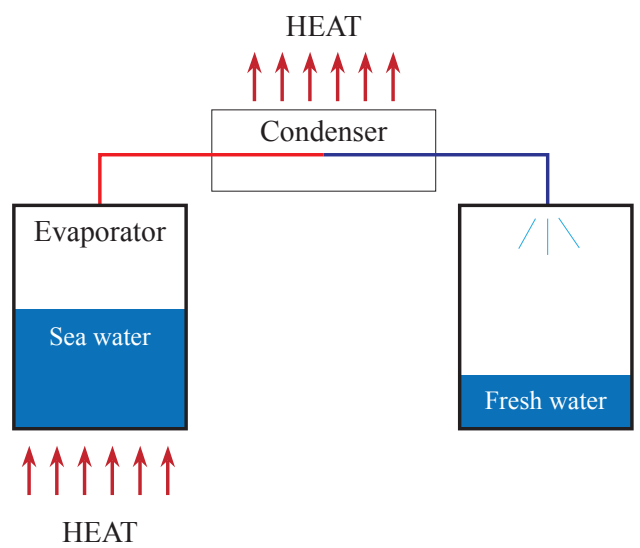




\section{Concept of a heat pump}

A heat pump is a thermodynamic system whose function is to move heat energy from one environment to another and for that uses a refrigeration cycle, is composed of a condenser, an evaporator, a compressor and an expansion valve.

The thermodynamic cycle that occurs in a heat pump per compression cycle will be explained step by step through the case of a heat pump designed for the production of domestic hot water (Fig. 3), because the thermodynamically functioning is the same as in the heat pumps used in other applications.

In point (1) the refrigerant fluid is in a phase of mixing of liquid with a certain percentage of vapor and at low pressure, because it comes from the expansion valve, therefore its temperature is also low; in this state the refrigerant enters the evaporator, where it absorbs heat from the outside and changes its phase to saturated dry steam (2). In point (2) the refrigerant is found as saturated dry steam and thus enters the compressor, where it is compressed raising its pressure and therefore, its temperature (3), for this the compressor needs external energy which obtains it from an electrical or thermal source. From point (3) to (4) the refrigerant flows through the condenser, yielding energy to another contact fluid, which in the case of Fig. 3 corresponds to sanitary water. Finally, the coolant flows from point (4) to point (1) through the expansion valve, decreasing its pressure and temperature, remaining in the ideal condition to start the cycle again.

\section{Methodological Framework}

Once the theoretical concepts have been explained, the identification of the idea of the present study will be explained. A process is proposed that begins by separating the seawater from its salts through the evaporation of seawater, by means of the heat input it receives from the heat pump condenser. In other words, the heat transferred by the refrigerant will be used in the condensation process, in the change of the seawater phase from liquid to vapor, obtaining as products, desalinated water vapor and brine waste. To obtain desalinated water, the water vapor obtained from the condenser of the heat pump must be condensed. For this, an exchange of heat in the evaporator of the system is proposed between the coolant, which is at a low temperature, and the water vapor, which is at a high temperature. In other words, the refrigerant liquid will absorb the heat of the water vapor and will pass from the liquid to the gaseous phase, while, at the same

Fig. 3. Thermodynamic cycle of a heat pump (Calor y frío, 2015).

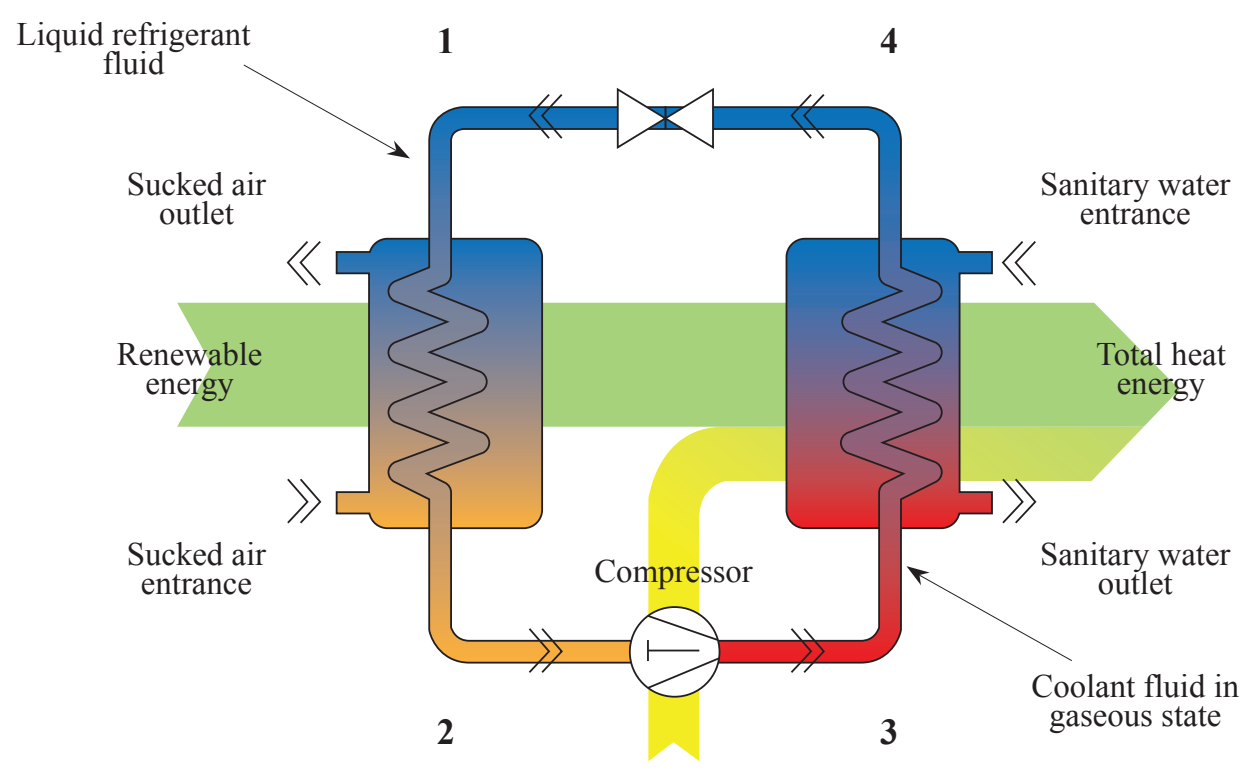


Fig. 4. Diagram of a seawater desalination heat pump (own elaboration).

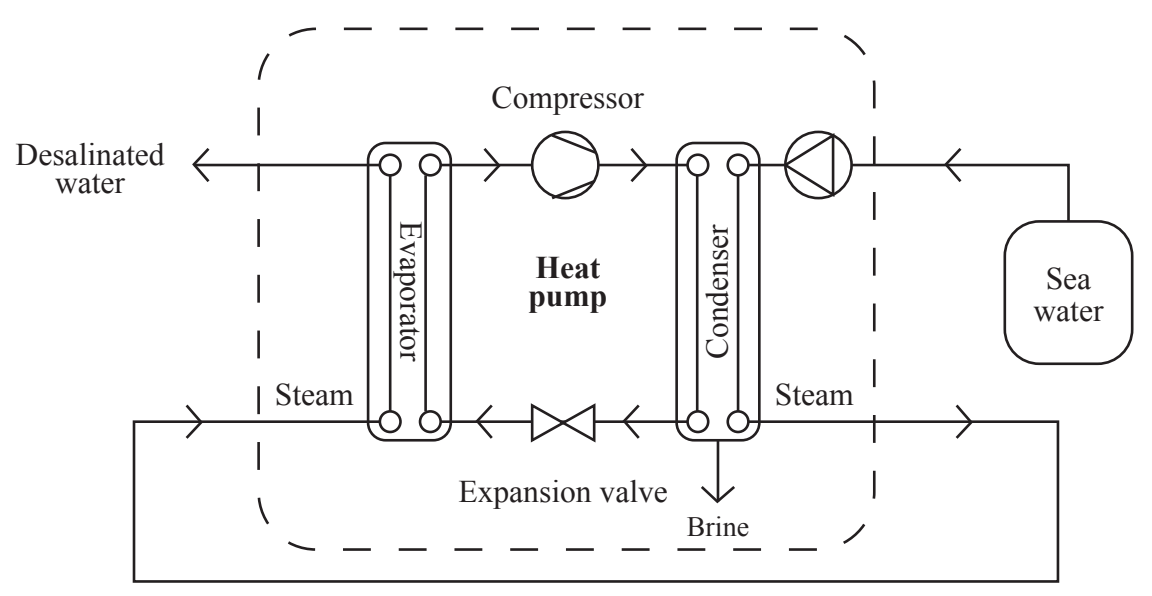

time, the water vapor will condense, obtaining as final product: desalinated water (Fig. 4).

To determine that the proposal described in the previous paragraph is really viable, different parameters had to be established such as: the application area and the desalinated water flows for each case, the geographical delimitation of the study and, accordingly, to establish the parameters of the seawater; determine the most suitable refrigerant and calculate the capacity that each component of the heat pump must possess.

It was established that the application area of the desalination system would be oriented to the Chilean Navy, for it was thought of three fields of action that are seen or could be affected by the scarcity of water. First, a unit afloat, since eventually a vessel may have its autonomy restricted due to the lack of potable water on board. Second the Marine infantry, especially in its operations in desert areas and finally the lighthouses inhabited in the extreme zone. And finally, the lighthouses inhabited in the southern area.

Within the afloat Units, a Chilean frigate was chosen, which has reverse osmosis as a desalination system and has a maximum desalination capacity of 25 [m3] per day. Its endowment is 160 people and to satisfy the normal water requirements they need to desalinate $15[\mathrm{~m} 3]$ per day, for the present study they will be considered the latter conditions, which is equivalent to $625[\mathrm{~L}]$ per hour.
For the Marine Corps, the Logistic Battalion, generally distributes the water requirements by Marine Companies, the Marine Company are composed of 132 people and are considered 23 [L] per person per day, which equals 126.5 [L] per hour.

In the case of inhabited lighthouses, the Maritime Signaling Service indicated that the lighthouses: Evangelical Islets, Fairway Islets, Felix Bay and Diego Ramirez Islands are currently facing water supply problems, as they are collected through rainwater, which together with the bad conditions of wind and sea, most of the time is salty and unfit for human consumption. The endowments of these four lighthouses on average is 5 people, as mentioned at the beginning, a person consumes approximately 200 [L] of water per day, which gives a total of a consumption of 1000 [L] per day per lighthouse, equivalent to 42 [L] per hour. Table 2 shows a summary of the flows that will be considered in the present study according to the area of application.

The geographical delimitation of the study was centered in Chile according to the northern, central and southern zones, and statistical studies were carried out to determine the representative data of the surface measurements of seawater delivered by the Hydrographic and Oceanographic Service of the Navy. Density, specific heat, salinity and temperature of the coast of Iquique, for the northern zone, an average between Valparaíso and Talcahuano, for the central zone and Punta 
Table 2. Flows of desalinated water according to number of people (own elaboration).

\begin{tabular}{|c|c|c|c|c|}
\hline & & PEOPLE & $\begin{array}{l}\text { VOLUME } \\
\text { FLOW RATE }\end{array}$ & $\begin{array}{l}\text { VOLUME FLOW } \\
\text { RATE }\end{array}$ \\
\hline Flow 1 & Living lighthouse & 5 & 1.000 & 42 \\
\hline Flow 2 & Marine company & 132 & 3.036 & 127 \\
\hline Flow 3 & Frigate & 160 & 15.000 & 625 \\
\hline
\end{tabular}

Arenas for the southern zone. Table 3 indicates the results obtained.

For the refrigerant, hydrofluorocarbons or HFCs were studied, since they do not have chlorine in their composition, an element that directly affects the destruction of the ozone layer, within the HFCs those of classification A1 were chosen, this means that It is not flammable and has low toxicity, and among those selected, refrigerant gas $134 \mathrm{a}$ is the most suitable because it is regularly used in heat pumps and works at medium and high temperatures, that is to say at $0^{\circ} \mathrm{C}$.

Table 3. Parameters representative of sea water according to geographical area (own elaboration).

\begin{tabular}{|c|c|c|c|c|c|}
\hline ZONE & PORTS & $\begin{array}{c}\text { TEMPERATURE } \\
{\left[{ }^{\circ} \mathrm{C}\right]}\end{array}$ & $\begin{array}{l}\text { SPECIFIC HEAT } \\
\text { CAPACITY }\end{array}$ & $\begin{array}{c}\text { DENSITY } \\
{\left[\mathrm{Kg} / \mathrm{m}^{3}\right]}\end{array}$ & $\begin{array}{l}\text { SALINITY } \\
\text { [PSU] }\end{array}$ \\
\hline NORTH & Iquique & 15,23 & 3,89 & 1025,09 & 34,86 \\
\hline CENTER & Valparaíso/Talcahuano & 13,74 & 3,89 & 1025,53 & 33,97 \\
\hline SOUTH & Punta Arenas & 8,58 & 3,9 & 1025,53 & 32,95 \\
\hline
\end{tabular}

Finally, the calculation of the capacities for each component of the heat pump, that is, the heat transferred by the condenser, the heat absorbed by the evaporator and the power required by the compressor, through the procedure indicated below:

In the condenser of the heat pump, as its name indicates, the refrigerant will be condensed, but at the same time, the seawater will evaporate, with the objective of obtaining as product, steam, brine and condensed refrigerant liquid, but how much heat do you need to achieve it? The total heat is the sum of the sensible heat and the latent heat and it's equal to the sum of the heat of evaporation plus the power of the compressor (equation 1).

$$
\dot{Q}_{T}=\dot{Q}_{S}+\dot{Q}_{L}=\dot{Q}_{E v}+\dot{W}
$$

$\dot{Q}_{T}:$ Total heat [W]

$\dot{Q}_{S}:$ Sensible heat [W]

$\dot{Q}_{L}:$ Latent heat $[W]$

$\dot{Q}_{E v}:$ Evaporation heat [W]

$\dot{W}$ : Compressor power [W]
To calculate the sensible and latent heat equations 2 and 3 were used.

$$
\begin{aligned}
& \dot{Q}_{S}=\dot{m} * c\left(T_{f}-T_{i}\right) \\
& \dot{Q}_{L}=\dot{m} * h_{f g}
\end{aligned}
$$

$m:$ Seawater mass flow $[\mathrm{Kg} / \mathrm{s}]$

$c$ : Specific heat of seawater $\left[K J /{ }^{\circ} C^{*} \mathrm{Kg}\right]$

$T_{f}$ : Final temperature of seawater $\left[{ }^{\circ} \mathrm{C}\right]$

$T_{i}$ : Initial temperature of seawater $\left[{ }^{\circ} \mathrm{C}\right]$

$h_{f g}$ : Difference of water saturation enthalpies $[J / K g]$

The variables that have not yet been determined are: the seawater mass flow rate, the final evaporation temperature and the water saturation enthalpies difference, since the initial temperature and the specific heat of seawater are indicated in the Table 3. The mass flow of seawater will be calculated through equation (4), from the volumetric flow of desalinated water indicated in Table 2 and, depending on the geographical area, the densities and salinities determined in Table 3 will be used. 


$$
\begin{aligned}
& \dot{m}=\dot{q}_{a} * \frac{\rho}{1000} \\
& \dot{q}_{a}=\frac{\dot{q}_{f}}{\left(1-\frac{S_{a}}{\rho}\right)}
\end{aligned}
$$

$\dot{q}_{a}$ : Volumetric flow of seawater $[L / h]$

$\rho:$ Seawater density $\left[\mathrm{Kg} / \mathrm{m}^{3}\right]=[g / L]$

$\dot{q}_{f}$ : Volumetric flow of desalinated water $[L / h]$

$S_{a}:$ Salinity of seawater $[p s u]=[g / L]$

To determine the evaporation temperature of seawater, it must first be indicated that it depends on the pressure of the circuit. The idea is to establish a boiling temperature of sea water less than that corresponding to atmospheric pressure, for this the circuit must be empty. For the present study to be adjusted to reality, the evaporation temperature was considered equal to that used in the on-board evaporators, that is $70\left[{ }^{\circ} \mathrm{C}\right]$ (Salinas, 2015), corresponding to a pressure of $31,202[\mathrm{kPa}]$ (Cengel, 2011).

With the mass flow rate and the established evaporation temperature, the $\mathrm{h} \_f g$ equivalent to 2.333,0 [kJ/kg] (Cengel, 2011), from the above you can calculate the sensible heat, the latent heat and therefore the total heat $\left(\dot{Q}_{T}\right)$.

On the other hand, equation (6) was used to calculate the heat of evaporation.

$$
\begin{aligned}
& \dot{Q}_{E v}=\dot{m}_{R F} *\left(h_{1}-h_{4}\right) \\
& \dot{m}_{R F}=\frac{\dot{Q}_{T}}{h_{2-3}}
\end{aligned}
$$

$m_{R F}:$ Mass flow coolant $[\mathrm{Kg} / \mathrm{s}]$

$h_{1,2,3,4}$ : Enthalpy coolant according to Fig. 5. [W]

To set the value of $h_{2-3}$ The temperature of the refrigerant must be determined upon entering the compressor. "A common value that is taken into account for the condenser is a temperature difference of $20^{\circ} \mathrm{C} "$ (Silva, 2012), between the medium (sea water) and the refrigerant; that is, a temperature of $90\left[{ }^{\circ} \mathrm{C}\right]$ will be considered for the refrigerant, which corresponds to an enthalpy of 82.35[kJ/kg] (Cengel, 2011).

Fig. 5. Pressure-enthalpy diagram of the refrigeration cycle (Cengel, 2011).

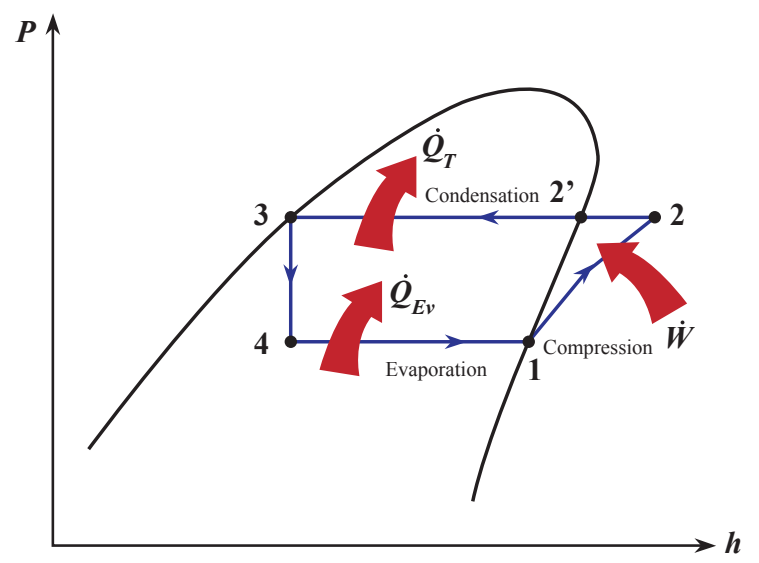

To determine $h_{4}$, it should be mentioned that the enthalpy in point (4) is equal to that of point (3) (Fig. 5), so you must enter the refrigerant table R-134a (Cengel, 2011) with the $T_{r f}=90\left[{ }^{\circ} \mathrm{C}\right]$ and verify the enthalpy of saturated liquid, which equals $h_{3}=h_{4}=194,76[\mathrm{~kJ} / \mathrm{kg}]$. While to establish enthalpy $h_{1}$, first determine the temperature of desalinated water that you want to obtain as a product. "The water for the drink should not be cold or hot, in both cases it affects the muscles of the stomach and all the movement of the digestive system, the ideal temperature should oscillate between $10\left[{ }^{\circ} \mathrm{C}\right]$ y $22\left[{ }^{\circ} \mathrm{C}\right] "$ (Costas, 2002). On the other hand, according to Silva (2012), in an evaporator, the difference of the temperature of the coolant with the medium (water vapor), is recommended $10\left[{ }^{\circ} \mathrm{C}\right]$.

Therefore, for the present titration work, a temperature will be established for the desalinated water of $T_{a d}=20\left[{ }^{\circ} \mathrm{C}\right]$, therefore, the coolant temperature will be $10\left[{ }^{\circ} \mathrm{C}\right]$. To get the enthalpy $h_{1}$, you must enter the refrigerant table R-134a (Cengel, 2011) with the $T_{r f}=10\left[{ }^{\circ} \mathrm{C}\right]$ and verify the enthalpy of saturated dry steam, which equals $h_{1}$ $=256,16[\mathrm{~kJ} / \mathrm{kg}]$. The power of the compressor was established (equation (1)) and through this the size 
of the heat pump will be dimensioned and it will be determined, conceptually, if it is an effective system to desalinate seawater according to the conditions of the coast From Chile. In addition, the coefficient of performance (COP) was established through equation (8).

$$
\begin{aligned}
& \dot{Q}_{T}=\dot{Q}_{S}+\dot{Q}_{L}=\dot{Q}_{E v}+\dot{W} \\
& C O P=\frac{Q_{T}}{\dot{W}}
\end{aligned}
$$

Table 4 shows the results obtained, which indicates that the power of the heat pump is not affected significantly by the differences in the parameters according to geographical area, therefore standardized characteristics were established according to Table 5. The COP of 3.93 indicates that the total energy that the refrigerant gives to the seawater in the condenser and almost four times the power required by the compressor, which implies efficiency greater than any other thermal machine.
As a technical proposal, real commercial-level components that complied with the proposed specifications were selected, with which the viability of the project will be indicated, but it will not be determined that the chosen component is the most appropriate.

In the case of the evaporator and the condenser, heat exchangers of the shell and tube type were investigated, for which the heat transfer area had to be calculated, with these data it was verified that there are shell heat exchangers and tubes that meet with the requirements, an example of this is the SSCF or EF model of the company Standard Xchange.

For the selection of a compressor that meets the specified specifications, the United Technologies Corporation (UTC) Spare Parts Catalog was chosen, Table 6 shows some of the compressors that meet the requirements necessary to be part of the desalination system using a heat pump, also

\begin{tabular}{|c|c|c|c|c|c|}
\hline CASES & ZONE & $\begin{array}{c}\text { VOLUME } \\
\text { FLOW RATE } \\
\text { qf }[\mathrm{L} / \mathrm{h}]\end{array}$ & $\mathrm{Q}_{\mathrm{T}}[\mathrm{KW}]$ & $\mathrm{Q}_{\mathrm{EV}}[\mathrm{KW}]$ & $\mathrm{W}$ [KW] \\
\hline \multirow{3}{*}{$\begin{array}{l}\text { Living } \\
\text { lighthouse }\end{array}$} & NORTH & \multirow{3}{*}{42} & 31,52 & 23,5 & 8,02 \\
\hline & CENTER & & 31,58 & 23,54 & 8,03 \\
\hline & SOUTH & & 31,8 & 23,71 & 8,09 \\
\hline \multirow{3}{*}{$\begin{array}{l}\text { Marine } \\
\text { company }\end{array}$} & NORTH & \multirow{3}{*}{127} & 95,31 & 71,07 & 24,25 \\
\hline & CENTER & & 95,48 & 71,19 & 24,29 \\
\hline & SOUTH & & 96,16 & 71,7 & 24,46 \\
\hline \multirow{3}{*}{ Fragata } & NORTH & \multirow{3}{*}{625} & 469,07 & 349,73 & 119,33 \\
\hline & CENTER & & 469,91 & 350,36 & 119,54 \\
\hline & SOUTH & & 473,23 & 352,84 & 120,39 \\
\hline
\end{tabular}

Table 4. Capacities per component of the heat pump.

\begin{tabular}{|c|c|c|c|c|c|}
\hline CASES & $\begin{array}{c}\text { VOLUME FLOW } \\
\text { RATE }[\mathrm{L} / \mathrm{h}]\end{array}$ & $\mathrm{Q}_{\mathrm{T}}[\mathrm{KW}]$ & $\mathrm{Q}_{\mathrm{EV}}[\mathrm{KW}]$ & $\mathrm{W}[\mathrm{KW}]$ & $\mathrm{COP}$ \\
\hline $\begin{array}{l}\text { Living } \\
\text { lighthouse }\end{array}$ & 42 & 32 & 24 & 10 & \multirow{3}{*}{3,93} \\
\hline $\begin{array}{l}\text { Marine } \\
\text { company }\end{array}$ & 127 & 97 & 72 & 25 & \\
\hline Frigate & 625 & 475 & 353 & 120 & \\
\hline
\end{tabular}

Table 5. Standardized capacities per component of the heat pump. 
Table 6. Compressor selection according to catalog (own preparation).

\begin{tabular}{|c|c|c|c|c|c|}
\hline CASES & $\begin{array}{c}\text { VOLUME FLOW } \\
\text { RATE qf }\end{array}$ & $\mathrm{W}[\mathrm{KW}]$ & COMPRESSOR & $\begin{array}{l}\text { DIMENSIONS* } \\
{[\mathrm{cm}]}\end{array}$ & $\begin{array}{l}\text { WEIGHT } \\
{[\mathrm{Kg}]}\end{array}$ \\
\hline $\begin{array}{l}\text { Living } \\
\text { lighthouse }\end{array}$ & 42 & 11 & $\begin{array}{c}\text { Open Alternative } \\
\text { Carlyle-Carrier } \\
\text { model 5F40 }\end{array}$ & $\begin{array}{l}A=54,61 \\
B=48,26 \\
C=51,12\end{array}$ & 161 \\
\hline $\begin{array}{l}\text { Marine } \\
\text { company }\end{array}$ & 127 & 29 & $\begin{array}{c}\text { Open Alternative } \\
\text { Carlyle-Carrier } \\
5 \mathrm{H} 46\end{array}$ & $\begin{array}{l}A=77,47 \\
B=62,23 \\
C=73,66\end{array}$ & 277 \\
\hline Frigate & 625 & 136,5 & $\begin{array}{l}\text { Rotary Screw } \\
\text { Carlyle-Carrier } \\
\text { model } 06 \mathrm{~N}\end{array}$ & Not available & 380 \\
\hline
\end{tabular}

Information obtained from: Catálogo de repuestos (UTC). *Dimensions according Fig. 6.

indicating the dimensions and / or the weight in each case (Fig. 6).

Fig. 6. Open reciprocating compressor Carlyle-Carrier models 5F \& 5H (United Technologies Corporation (UTC), 2017)

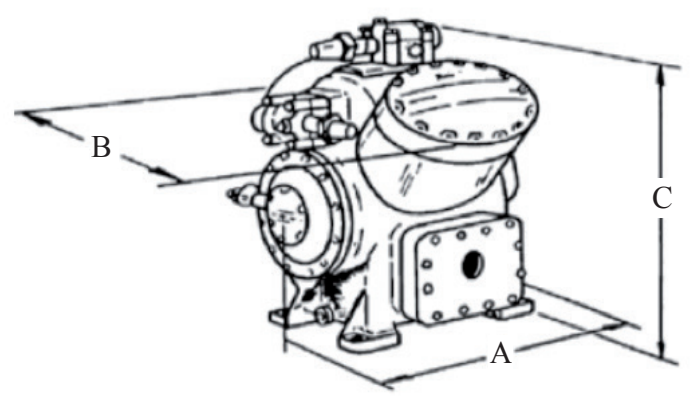

\section{Conclusions}

1. The variation of the parameters due to their geographic location does not significantly affect the power required by the heat pump to desalinate a certain water flow, so that the same conceptual design can be used throughout the coast of the country.

2. It is not possible to determine that the proposed conceptual design constitutes a more or less adequate system than the reverse osmosis plants or evaporators that exist on board the units of the Chilean Navy.
3. Theoretically it can be concluded that the desalination system using a heat pump is more efficient than another evaporation desalination system, because its coefficient of performance equal to 3.93 is greater than that of any other thermal system, since that these have an efficiency lower than one.

4. According to the parameters and requirements established for the proposed conceptual design, it is established that it is possible to use commercial compressors, condensers and evaporators as basic components of the heat pump.

5. 5. Finally, through the established conceptual design, it is concluded that the technology of the heat pump is applicable to a seawater desalination system, considering the conditions and properties that the sea has in the studied zones of Chile.

\section{References}

CÁCERES, Ó. (2016). Reforma al Código de Aguas: los efectos del proyecto que limita los derechos de uso. Retrieved from http://www.biobiochile. $\mathrm{cl} /$ noticias/nacional/chile/2016/11/22/ reforma-al-codigo-de-aguas-los-efectos-delproyecto-que-limita-los-derechos-de-uso. shtml 
AGUAS ANDINAS. (2017). Aguas Andinas. Retrieved from https://www.aguasandinas.cl/ la-empresa/que-hacemos/consumo

MARTIN, G. \&. (2017). What is diffusion? Retrieved 5 3, 2017, from http://qcpages. qc.cuny.edu/ instr\%5Cjgao104/diffusion. html

CENGEL, B. (2011). Termodinámica. New York, Estados Unidos: Mc Graw Hill.

CALOR Y FRÍO. (2015). Funcionamiento de la bomba de calor para calefacción y agua caliente. Retrieved 08 25, 2017, from https://www. caloryfrio.com/calefaccion/bomba-de-calor/ bomba-de-calor.html

UNITED TECHNOLOGIES CORPORATION (UTC) . (2017). Carrier. Retrieved 09 22, 2017, from http://www.carrier.es/manuales/ CATALOGO_UTC.pdf
AlteagA, J. A. (2016). Diseño conceptual. Retrieved Julio 31, 2017, from https:// www.coursehero.com/file/17966444/ Dise\%C3\%B1o-conceptual/

SILVA, G. G. (2012, 02 12). Cero grados celsius. Retrieved 09 20, 2017, from https:// www.0grados.com/diferencia-de-temperaturaen-sistemas-de-refrigeracion-y-aireacondicionado/

COSTAS, M. (2002). H2O Agua. Retrieved 09 20, 2017, from Asesoría Nutricional: http:// asesorianutricional.com.ar/h2oagua.htm

SALINAS, R. (2015). Análisis comparativo de plantas de osmosis inversa y evaporadores a bordo de la Escuadra. Valparaíso, Chile. 